\title{
A Model for the Management of Cultural Tourism at Temples in Bangkok, Thailand
}

\author{
Phra Thanuthat Nasing ${ }^{1}$, Chamnan Rodhetbhai ${ }^{1}$ \& Ying Keeratiburana ${ }^{1}$ \\ ${ }^{1}$ The Faculty of Cultural Science, Mahasarakham University, Khamriang Sub-District, Kantarawichai District, \\ Maha Sarakham Province, Thailand \\ Correspondence: Phra Thanuthat Nasing, The Faculty of Cultural Science, Mahasarakham University, Khamriang \\ Sub-District, Kantarawichai District, Maha Sarakham Province 44150, Thailand. E-mail: snasing134@gmail.com
}

\author{
Received: May 20, 2014 Accepted: June 12, 2014 Online Published: June 26, 2014 \\ doi:10.5539/ach.v6n2p242 URL: http://dx.doi.org/10.5539/ach.v6n2p242
}

\begin{abstract}
This qualitative investigation aims to identify problems with cultural tourism in nine Thai temples and develop a model for improved tourism management. Data was collected by document research, observation, interview and focus group discussion. Results show that temples suffer from a lack of maintenance, poor service, inadequate tourist facilities, minimal community participation and inefficient public relations. A management model to combat these problems was designed by parties from each temple at a workshop. The model provides an eight-part strategy to increase the tourism potential of temples in Bangkok: temple site, safety, conveniences, attractions, services, public relations, cultural tourism and management.
\end{abstract}

Keywords: management, cultural tourism, temples, Thailand, development

\section{Introduction}

When Chao Phraya Chakri deposed King Taksin of the Thonburi Kingdom in 1982, he relocated the Siamese capital city to Bangkok and revived society under the name of his new Rattanakosin Kingdom (Prathepweti, 1995). Although royal monasteries had been commissioned much earlier in Thai history, there was a particular interest in their restoration during the reign of the Rattanakosin monarchs. This restoration established a 'conservation-mentality' towards Thai tangible heritage, which is now used to add value to the national economy through the medium of tourism (Angkoon et al., 2001; Tourism Authority of Thailand, 1996).

Temples in Bangkok benefit from their beautiful location, open policy to tourism and dedication of resident monks to the inheritance and transmission of knowledge (Angkoon et al., 2001). However, the same temples suffer because tourists are ignorant of correct and respectful behaviour, guides are unqualified, staff lack service mentality and scams are widespread (Sukhothai Thammathirat Open University, 2002). Although there are trends towards experience and knowledge-based travel, raw information is not enough to satisfy the modern tourist (Piwnim \& Jansupan, 2003). With this in mind, the research team aim to identify the specific problems with cultural tourism management in Rattanakosin-era temples in Bangkok and design a model for its development.

\section{Literature Review}

Cultural tourist attractions are places or resources with value in art, customs and traditions that have been inherited over time from previous generations (Jantorn, 2002). The lack of resource conservation is the biggest modern-day problem with tourism in Thailand (Kosit et al., 2007). The environment, ancient architecture and artefacts are all neglected due to a lack of community participation and interest (Laomee, 2009). The most important considerations for cultural tourist attractions are accessibility, guest conveniences, value of the tourist attraction and the surrounding environment (Buarapa, 2006; Chaisorn, 1993; Hiranyahat, 2001; Pakpinpet, 2008). In order for cultural tourist activities to work, a selling point must be developed (Chantachon, 2006). However, the appeal of attractions for domestic visitors and international visitors differ. While heritage is the primary draw for Thai tourists, it is less of a concern for foreign tourists (Peleggi, 1996).

Buddhist temples in Thailand are centres of religion, fine arts and education that constitute a large part of the cultural tourist attractions in Thailand (Kaewmuang \& Limpaluwan, 1998). Thai temples carry high historical and artistic value (Menakanit, 1999). According to Pra-atikarnsupot Sripanya (2009), tourists are attracted to temples for the art and architecture, religious and cultural activities, the surrounding environment and Vipassana meditation. The strengths of temples as tourist attractions in Thailand are their accessibility and attractiveness, 
while their weaknesses are public conveniences and information services (Nantee, 2001). The Department of Religious Affairs (1994) created a model for the improvement and conservation of temples and their artistic contents. The conclusions of the model showed that monks play a vital role in temple conservation because they must teach tourists how to behave and act appropriately in the temple grounds. However, monks cannot be made solely responsible for improvements due to their limitations in language and communication skills (Angkoon et al., 2001). Patcharee Linitta (2012) highlights service deficiencies as the biggest threat to cultural tourism in Thai temples. Four solutions to this offered by Natchanok Nantee (2001) are structural management of tourism organisation, personnel management, work system management and management of an appropriate cultural tourism program. A tourist-friendly temple environment must be clean, with clear information, signage in many languages and sufficient public amenities (Prakru-wijitsangkakarn, 2009). Cultural activities and transport security are further concerns (Phromsarametee, 2010).

The nine important steps that must be taken to prepare for cultural tourism, as outlined by Michael Coltman (1989) are: 1) increasing awareness among locals as to the importance of tourism for the economy, society and community; 2) deciding how much or how little change the local community wishes to make to its everyday environment; 3) determining method and style of advertising to attract a certain kind of tourist; 4) initiating cooperation between the government and private sectors; 5) preventing harmful effects on the local people and environment; 6) hiring personnel from the local area; 7) providing opportunities for the local community to participate in activities and festivals; 8) ensuring activities and festivals reveal the local history and culture; 9) solving community problems before beginning a cultural tourism initiative. The steps outlined by Coltman place a high level of importance on the local community and many studies have been conducted that treat local participation as vital to the successful management of cultural tourist attractions (Cohen \& Uphoff, 1977; Irwin, 1976; Koontz, O’Donnel \& Weihrich, 1986; McGregor, 1960; Wisalaporn, 1991). Nutsinee Yotprakorn (2004) made eight suggestions for management of cultural tourist attractions in Thailand: 1) management staff must define a working plan and set of objectives; 2) tourist businesses must conduct a questionnaire to gather tourist opinion about their attraction; 3) staff must perform their duties comprehensively; 4) there must be support for work development; 5) there must be improvements and renovations of physical tourist attractions; 6) there should be examination of the factors that lead tour companies to select certain attractions; 7) there must be investigation of market changes and developments; 8) there must be research of future government tourism policies. These ideas correspond to the foundations for sustainable tourism addressed by Shirley Eber (1992) and multidisciplinary studies on the development of cultural tourism (Holloway, 1998; Hongsurapha, 2009; Swarbrooke, 1999).

\section{Methodology}

This qualitative investigation employs both documentary research and field study. The research area was purposively selected as nine Rattanakosin period temples and their surrounding communities in Bangkok (Table 1). Selection was based on two criteria: 1 ) the temples must have been royally commissioned by the Thai King; 2 ) they had to be temples affected by five independent variables - location, tourist safety, public interest, public conveniences and tourist activities. The research was conducted from $15^{\text {th }}$ January 2012 until $30^{\text {th }}$ September 2012. Informants for the research were divided into three groups. Group one (key informants) was composed of an official from the Bureau of the Royal Household, an official from the Department of Religious Affairs, an official from the National Office of Buddhism and academics from the Department of Religious Affairs and the Department of Fine Arts. Group two (casual informants) was composed of abbots and their assistants, monks and temple wardens from each of the nine Rattanakosin temples. Group three (general informants) was composed of domestic and foreign tourists to the temples and local people in the surrounding communities. There were 118 informants in total.

Table 1. Temples studied during this research

\begin{tabular}{lc}
\hline Temple & Location \\
\hline Wat Phra Chettuphon Wimon Mangkhlaram (Wat Pho) & Phra Nakhon District, Bangkok \\
Wat Arun Ratchawararam (Wat Arun) & Phra Nakhon District, Bangkok \\
Wat Ratcha Orasaram & Chom Thong District, Bangkok \\
Wat Ratchapradit Sathit Mahasimaram (Wat Ratchapradit) & Phra Nakhon District, Bangkok \\
Wat Benchamabophit Dusitvanaram (The Marble Temple) & Dusit District, Bangkok \\
Wat Bowonniwet Vihara & Phra Nakhon District, Bangkok \\
Wat Ratchabophit Sathit Maha Simaram (Wat Ratchabophit) & Phra Nakhon District, Bangkok \\
Wat Suthat Thep Wararam & Bangkok Yai District, Bangkok \\
Wat Pram 9 Kanjanaphisek (Rama IX Golden Jubilee Temple) & Huai Khwang District, Bangkok \\
\hline
\end{tabular}


Secondary data for this investigation was collected from documents concerning the status, role, function and conditions of tourism in Rattanakosin period temples. Primary data was collected by participant and non-participant observation, interview and focus group discussion. The formal interview was conducted in six parts. The first part asked for personal details of the respondent; the second part asked basic questions about temples used for cultural tourism; the third part asked about the role of temples in promoting cultural tourism; the fourth part asked about the conditions required for temples to be cultural tourist attractions; the fifth part asked about the problems with cultural tourism in Rattanakosin temples under eight categories - the temple site, safety, conveniences, attractions, service capacity, public relations, cultural tourism and management; the sixth part asked for suggestions to develop cultural tourism in the Rattanakosin temples of Bangkok (Table 2). The focus group discussions were held with four to five individuals from each temple area and had five clear functions:

- To consult related personnel, temple management and committee members, government and private institutions, in order to define a set of approaches to improve cultural tourism at the temples.

- To define roles for the temple artefacts, buildings, knowledge and staff.

- To discuss the problems with tourism management in the temples in eight categories: the temple site, safety, conveniences, attractions, service capacity, public relations, cultural tourism and management.

- To analyse the current conditions of tourism in the temples by SWOT analysis, in order to determine strengths, weaknesses, opportunities and threats.

- To establish guidelines for a workshop with the aim of defining a development model for cultural tourism in Rattanakosin temples.

Table 2. A list of interview respondents

\begin{tabular}{lcc}
\hline Name & Date Interviewed & Location \\
\hline Adisak Rattanahaem & $14 / 2 / 2012$ & Wat Bowonniwet Vihara \\
Amnat Buasiri & $25 / 2 / 2012$ & Phutthamonthon Buddhist Park \\
Amnat Promkaew & $1 / 2 / 2012$ & Wat Ratchapradit Sathit Mahasimaram \\
Amporn Sripreotikoon & $10 / 2 / 2012$ & Wat Ratcha Orasaram \\
Carmen Carine & $15 / 2 / 2012$ & Wat Bowonniwet Vihara \\
Chaloempon Chanamarn & $9 / 2 / 2012$ & Wat Praram 9 Kanjanaphisek \\
Chantana Peungsai & $5 / 2 / 2012$ & Wat Phra Chettuphon Wimon Mangkhlaram \\
Cheupat Wijitsuntarakoon & $2 / 2 / 2012$ & Wat Suthat Thep Wararam \\
Cholapatsorn Akkarawongpan & $9 / 2 / 2012$ & Wat Praram Kanjanaphisek \\
Chutima Taesilapachai & $5 / 2 / 2012$ & Wat Benchamabophit Dusitvanaram \\
Clayton Shark & $15 / 2 / 2012$ & Wat Phra Chettuphon Wimon Mangkhlaram \\
Deborah Shlian & $17 / 2 / 2012$ & Wat Benchamabophit Dusitvanaram \\
Dogget Wise & $20 / 2 / 2012$ & Wat Ratchabophit Sathit Maha Simaram \\
Federigo Sila & $15 / 2 / 2012$ & Wat Bowonniwet Vihara \\
Felipe Paredes & $21 / 2 / 2012$ & Wat Suthat Thep Wararam \\
Frederick Raignault & $16 / 2 / 2012$ & Wat Phra Chettuphon Wimon Mangkhlaram \\
Gulsun Winelend & $18 / 2 / 2012$ & Wat Arun Ratchawararam \\
Jiraporn Saleewattanapongkoon & $2 / 2 / 2012$ & Wat Suthat Thep Wararam \\
Jitana Ninnam & $5 / 2 / 2012$ & Wat Ratchabophit Sathit Maha Simaram \\
Joel Shlian & $17 / 2 / 2012$ & Wat Benchamabophit Dusitvanaram \\
Julie Lesage & $20 / 2 / 2012$ & Wat Ratchabophit Sathit Maha Simaram \\
Jutamas Sutirotrak & $2 / 2 / 2012$ & Wat Suthat Thep Wararam \\
Kanoklada Amyong & $14 / 2 / 2012$ & Wat Bowonniwet Vihara \\
Kantima Plienpangchang & $1 / 2 / 2012$ & Wat Ratchapradit Sathit Mahasimaram \\
Kathleen Junion & $16 / 2 / 2012$ & Wat Phra Chettuphon Wimon Mangkhlaram \\
Kornsuda Kotnan & $1 / 2 / 2012$ & Wat Ratchapradit Sathit Mahasimaram \\
\hline & &
\end{tabular}




\begin{tabular}{|c|c|c|}
\hline Name & Date Interviewed & Location \\
\hline Manuel Gliz & $18 / 2 / 2012$ & Wat Arun Ratchawararam \\
\hline Marc Paipon & $20 / 2 / 2012$ & Wat Ratchabophit Sathit Maha Simaram \\
\hline Maria Allegret & $10 / 2 / 2012$ & Wat Bowonniwet Vihara \\
\hline Marie Laure & $21 / 2 / 2012$ & Wat Ratchabophit Sathit Maha Simaram \\
\hline Metta Jaroenporn & $14 / 2 / 2012$ & Wat Bowonniwet Vihara \\
\hline Michael Bervill & $21 / 2 / 2012$ & Wat Suthat Thep Wararam \\
\hline Michael Kent & $21 / 2 / 2012$ & Wat Suthat Thep Wararam \\
\hline Michael Muner & $18 / 2 / 2012$ & Wat Arun Ratchawararam \\
\hline Michael Solapend & $18 / 2 / 2012$ & Wat Arun Ratchawararam \\
\hline Napadon Namboon & $2 / 2 / 2012$ & Wat Suthat Thep Wararam \\
\hline Natpapat Pannarangseeyakorn & $10 / 2 / 2012$ & Wat Ratcha Orasaram \\
\hline Nattapak Chawiwong & $1 / 2 / 2012$ & Wat Ratchapradit Sathit Mahasimaram \\
\hline Nora Mona & $15 / 2 / 2012$ & Wat Bowonniwet Vihara \\
\hline Pakorn Tansakoon & $29 / 2 / 2012$ & Suwannaramwittayakom School \\
\hline Paratya Joonpornsopa & $5 / 2 / 2012$ & Wat Phra Chettuphon Wimon Mangkhlaram \\
\hline Parinda Udomkiti & $5 / 2 / 2012$ & Wat Benchamabophit Dusitvanaram \\
\hline Patcharaporn Duangjanda & $9 / 2 / 2012$ & Wat Praram 9 Kanjanaphisek \\
\hline Pawinee Payungdee & $3 / 2 / 2012$ & Saranrom Park \\
\hline Peter Weist & $18 / 2 / 2012$ & Wat Arun Ratchawararam \\
\hline Phillip Mosoa & $17 / 2 / 2012$ & Wat Benchamabophit Dusitvanaram \\
\hline Phillips Worres & $15 / 2 / 2012$ & Wat Bowonniwet Vihara \\
\hline Piriya Chokboonmongkon & $14 / 2 / 2012$ & Wat Bowonniwet Vihara \\
\hline Piyaporn Wanchalem & $1 / 2 / 2012$ & Wat Ratchapradit Sathit Mahasimaram \\
\hline Pra Udonkanarak & $25 / 1 / 2012$ & Palisatit School \\
\hline Prakru Udomsangworn & $19 / 1 / 2012$ & Wat Phra Chettuphon Wimon Mangkhlaram \\
\hline Prakrupaiboon Sornkit & $16 / 1 / 2012$ & Wat Benchamabophit Dusitvanaram \\
\hline Prakrusopit Thammarangsri & $22 / 3 / 2012$ & Bodh Gaya, India \\
\hline Prakruwinaitaramanop Palapan & $19 / 1 / 2012$ & Wat Phra Chettuphon Wimon Mangkhlaram \\
\hline Pramahajamnong Satjawatee & $15 / 1 / 2012$ & Wat Arun Ratchawararam \\
\hline Pramahanarachon Kositmetee & $15 / 1 / 2012$ & Wat Ratchabophit Sathit Maha Simaram \\
\hline Pramahapeeradet Jittecho & $21 / 1 / 2012$ & Wat Bowonniwet Vihara \\
\hline Pramaharom Apimomo & $15 / 1 / 2012$ & Wat Arun Ratchawararam \\
\hline Pramahawichian & $25 / 1 / 2012$ & Palisatit School \\
\hline Prang Kaewpran & $19 / 2 / 2012$ & Wat Ratchabophit Sathit Maha Simaram \\
\hline Praratchaweti & $21 / 3 / 2012$ & Bodh Gaya, India \\
\hline Praratchayankawee & $19 / 1 / 2012$ & Wat Praram 9 Kanjanaphisek \\
\hline Prasiriwat Nodom & $22 / 1 / 2012$ & Wat Ratchabophit Sathit Maha Simaram \\
\hline Pratamm Kittiwong & $22 / 3 / 2012$ & Bodh Gaya, India \\
\hline Preecha Chumduang & $14 / 2 / 2012$ & Wat Bowonniwet Vihara \\
\hline Rabin Sornchai & $10 / 2 / 2012$ & Wat Ratcha Orasaram \\
\hline Raden Jandawan & $5 / 2 / 2012$ & Wat Phra Chettuphon Wimon Mangkhlaram \\
\hline Rampleung Tamboon & $5 / 2 / 2012$ & Wat Phra Chettuphon Wimon Mangkhlaram \\
\hline Rattana Jittrapakdee & $5 / 2 / 2012$ & Wat Benchamabophit Dusitvanaram \\
\hline Ruth Goldrammer & $21 / 2 / 2012$ & Wat Suthat Thep Wararam \\
\hline Sabine Minne & $21 / 2 / 2012$ & Wat Suthat Thep Wararam \\
\hline Samart Kunjaetong & $25 / 1 / 2012$ & Wat Phra Chettuphon Wimon Mangkhlaram \\
\hline Saowalak Poonjaroen & $10 / 2 / 2012$ & Wat Ratcha Orasaram \\
\hline
\end{tabular}




\begin{tabular}{lcc}
\hline Name & Date Interviewed & Location \\
\hline Saowalak Sapmak & $1 / 2 / 2012$ & Wat Ratchapradit Sathit Mahasimaram \\
Scotto Di Vettimo Antoine & $20 / 2 / 2012$ & Wat Ratchabophit Sathit Maha Simaram \\
Sergei Terkin & $16 / 2 / 2012$ & Wat Phra Chettuphon Wimon Mangkhlaram \\
Siraya Boonsaeng & $5 / 2 / 2012$ & Wat Phra Chettuphon Wimon Mangkhlaram \\
Suchada Nachanang & $5 / 2 / 2012$ & Wat Benchamabophit Dusitvanaram \\
Sunita Simala & $10 / 2 / 2012$ & Wat Ratcha Orasaram \\
Surachai Pimanaporn & $5 / 2 / 2012$ & Wat Phra Chettuphon Wimon Mangkhlaram \\
Suwan Siptat & $5 / 2 / 2012$ & Wat Benchamabophit Dusitvanaram \\
Suwichan Bunkeutkoon & $5 / 2 / 2012$ & Wat Phra Chettuphon Wimon Mangkhlaram \\
Tannakorn Sinpo & $14 / 2 / 2012$ & Wat Bowonniwet Vihara \\
Tawatchai Ratchadawan & $5 / 2 / 2012$ & Wat Benchamabophit Dusitvanaram \\
Teewara Kokeut & $19 / 2 / 2012$ & Wat Ratchabophit Sathit Maha Simaram \\
Victor Yorkchawov & $16 / 2 / 2012$ & Wat Phra Chettuphon Wimon Mangkhlaram \\
Wichien Anantasirirat & $2 / 2 / 2012$ & Ministry of Culture \\
Wilawan Wanloptaree & $10 / 2 / 2012$ & Wat Ratcha Orasaram \\
William Walsh & $17 / 2 / 2012$ & Wat Benchamabophit Dusitvanaram \\
Wipada Akarawanit & $10 / 2 / 2012$ & Wat Ratcha Orasaram \\
Wiroot Kaewchongkam & $19 / 2 / 2012$ & Wat Ratchabophit Sathit Maha Simaram \\
Yaruslav Gabriel Valdiuin & $17 / 2 / 2012$ & Wat Benchamabophit Dusitvanaram \\
Yongyut Prasitnok & $9 / 2 / 2012$ & Wat Praram 9 Kanjanaphisek \\
\hline
\end{tabular}

Data was sorted according to the two aims of the research: to determine problems with the current status of cultural tourism in Rattanakosin temples and to design a development method for cultural tourism in Rattanakosin temples. The data was validated by triangulation (Jantawanit, 2004). Data triangulation was conducted with the variables of time, place and respondent. Data was checked to see if results collected at different times, in different places and by different people agreed or disagreed. Investigator triangulation was used to test whether investigations conducted by different researchers yielded different outcomes. Theory triangulation was used to determine the effect on results if different theories were applied to the data. Finally, methodological triangulation was used to verify data collected by different means.

Data was analysed in three stages. For the first stage, data was gathered into four categories and analysed for meaning. The categories were: problems with cultural tourism; the status, role and function of Rattanakosin temples; the identity of Rattanakosin temples; the policies of Rattanakosin temples. For the second stage, cultural tourism in Rattanakosin temples was analysed with a SWOT technique, a development model for cultural tourism in Rattanakosin temples was designed and the design was taken to a workshop. The workshop, the third stage of analysis, was held on $29^{\text {th }}$ September 2012 at Suwannaramwittayakom School, Bangkok Noi District, Bangkok. Twenty people attended the workshop, a mixture of key, casual and general informants. The conclusions of research and analysis were presented to the group. These conclusions were evaluated and corrected so that a development model could be concluded for cultural tourism in Rattanakosin-era temples. The results are presented as a descriptive analysis.

\section{Results}

\subsection{Problems with the Management of Rattanakosin Period Temples}

There are problems with the management of cultural tourism in temples of the Rattanakosin period in eight major areas.

\subsubsection{The Temple Site}

'The temple area is dirty and full of animals. It is not looked after by the monks' (Prakrupaiboon Sornkit, 2012, interview). Locally released dogs and cats are free to roam the puttawat (worship) and sangkawat (monastic) areas of the temple, including the sacred spaces around Buddha idols. The strays patrol feeding locations and these are identified by food scraps and faeces on the floor. The dirtiness and odour are magnified during the wet season as rainwater disperses animal waste, food remnants and bird feed. Amplifying these problems further is 
the lack of litter bins and waste management (Kornsuda Kotnan, 2012, interview). There are no designated litter duties and the waste bins are left overflowing. Ground repairs and maintenance are rare, while basic tasks are left unperformed and cause such problems as fallen leaves covering the pathways. No attempt is made to disguise the aesthetic deficiencies by temple decoration or maintenance of temple gardens. This leaves the overall impression of the temples as dirty, smelly and unattractive (Jiraporn Saleewattanapongkoon, 2012, interview; Wilawan Wanloptaree, 2012, interview). The temple is a highly respected place in Buddhist culture that is used as a centre of religion, learning and society but the grounds are not maintained according to this status and there is no management system. Interview respondents indicated that 'there should be an attempt to make the areas more pleasant by planting more trees and maintaining the original culture' (Saowalak Poonjaroen, 2012, interview). Additionally, 'the landscape, cleanliness and temple regulations should be improved' (Kantima Plienpangchang, 2012, interview).

The temples suffer from the added problem of commercial exploitation. The sale of food and drinks is unregulated, while the biggest grievance among visitors is peddlers pushing their wares. The obstacle to solving this problem is that the hawkers conduct their business just outside the vicinity of the temples and thus outside the jurisdiction of the temple committee (Prakruwinaitaramanop Palapan, 2012, interview).

\subsubsection{Safety}

'Theft of tourist bags is a problem in the temple areas' (Suchada Nachanang, 2012, interview). Tourist footwear is also at risk when mandatorily left outside the worship area (Jitana Ninnam, 2012, interview). Touts collect parking fees from free car parks and the temple guides 'don't know the true history of the temples and just spout rubbish for the tourists. They're also in cahoots with the taxi drivers' (Samart Kunjaetong, 2012, interview). Both the guides and drivers get commission from sending tourists to local shops after they have visited the temples. Moreover, the paved segments of the temples are inadequately maintained and 'not safe for elderly visitors' (Peter Weist, 2012, interview). Accentuating these problems is the fact that 'nobody is assigned the responsibility to take care of tourists' (Amporn Sripreotikoon, 2012, interview).

\subsubsection{Conveniences}

There is insufficient car parking space for visitors (Wilawan Wanloptaree, 2012, interview; Maria Allegret, 2012, interview; Phillips Worres, 2012, interview). This causes traffic congestion around the temple and leads to private citizens offering their own land as parking space in return for financial gain. Insufficient parking is a problem for all Rattanakosin period temples, as is the lack of public assistance. Toilets are dirty and not always supplied with tissue or water (Dogget Wise, 2012, interview). In some temples, tourists are forced to use portable plastic toilets because there are no permanent facilities. There are few public telephones and automatic teller machines, there are no areas to sit and rest, power is unreliable, signposting is poor, there are no drinks shops and information is not provided for visitors (Saowalak Poonjaroen, 2012, interview). Overall, facilities, conveniences, 'cleanliness and order must be improved in the temples' (Kantima Plienpangchang, 2012, interview). A further consideration for temples is the lack of storage space for shoes around the worship area. Visitors must remove their shoes to enter the sacred parts of the temple but minimal provisions are made to hold the footwear. Foreign tourists also bemoan the lack of information in the English language: 'there should be staff members who can communicate in English' (Clayton Shark, 2012, interview), 'I want to see more English signs' (Manuel Gliz, 2012, interview), 'I would like the history of Buddhist statues and ornaments to be explained in English' (Yaruslav Gabriel Valdiuin, 2012, interview).

\subsubsection{Attractions}

The temples are worn out. 'The care of religious artefacts and buildings is not good enough and is not regulated' (Wilawan Wanloptaree, 2012, interview). This is largely because there are no members of temple staff with the required knowledge to manage repairs and restoration. This lack of experts also causes a lack of adequate information and research about the temples. No suggestions are sought or made for improving the visitor experience (Pratamm Kittiwong, 2012, interview). This problem of information flow extends to the guides and monks who inform and instruct at the temples. 'The expert monks and guides still lack methods to develop new techniques' (Praratchaweti, 2012, interview). There is no integration of new experiences, imagination and entertainment in the religious teachings, practical demonstrations or guide presentations.

\subsubsection{Service Capacity}

'There are not enough staff members to provide sufficient service to the tourists' (Prasiriwat Nodom, 2012, interview). Those staff members who are hired to support tourism at the temples do not possess the service mentality to do their jobs effectively. This includes the monks. There is a shortage of monks and an even bigger 
shortage of English-speaking monks (Prakruwinaitaramanop Palapan, 2012, interview).

\subsubsection{Public Relations}

There is minimal publicity for the temples and existing leaflets and flyers are only created in Thai and English languages. The temple guides also suffer from language limitations and many are unable to effectively communicate in English. Signage is inadequate and confusing, while the benefits of media are not fully exploited. Interview respondent opinions on these matters were clear and consistent:

'I would like to see more guides than this and also be given a brochure to explain about the history of the temple and its important artefacts' (Michael Kent, 2012, interview).

'There should be more English signs, staff members who can communicate in English and I want information about the temple history' (Carmen Carine, 2012, interview).

'There needs to be more temple publicity' (Federigo Sila, 2012, interview).

'I want to know more information about how the monks live' (Nora Mona, 2012, interview).

'There is no plan for the service, management and use of media' (Praratchaweti, 2012, interview).

'The development of Rattanakosin temple presentation is inefficient' (Prasiriwat Nodom, 2012, interview).

\subsubsection{Cultural Tourism}

Not all foreign tourists appreciate, are aware of or respect the customs and practices of Buddhism (Tanpronan, 1997). Western visitors wear inappropriate clothing, climb upon sacred statues and trespass in restricted areas. There are also conflicts between the temple councils and the monks about the tourism policy that should be adopted, which is ultimately decided by the abbots (Prasiriwat Nodom, 2012, interview). The divide is specifically between newer monks, who wish to develop cultural and religious activities for visitors to promote the cultural heritage of the Rattanakosin temples, and older monks, who wish to maintain the peace, tranquillity and holiness (Praratchaweti, 2012, interview).

'There are four reasons why people visit the temples: 1) they come to rest and recover; 2) they come to study and seek knowledge; 3) they come to participate in an important temple activity; 4) they come to admire the ancient site and artefacts. The temples must train their monks in the ability to provide information on these four fronts' (Pratamm Kittiwong, 2012, interview). The role of the monks, among other things, 'is to continue learning' so that they are able to provide their target group with the required information to enjoy their visit to the temple (Prakruwinaitaramanop Palapan, 2012, interview).

\subsubsection{Management}

Members of the management council are selected only from within the temple and there are no members from the local community, schools or government (Praratchaweti, 2012, interview). The only involvement of the government and the private sector is during large festivals. There is no systematic evaluation of temple management. The temples generate income from donations and tourism activities but there is neither structured management of the funding nor planning for its use.

\subsection{A Development Model for Cultural Tourism in Rattanakosin Temples}

Following documentary research, observation and interviews, the research team organised focus group discussions and workshops in each of the nine temples investigated. The activities were aimed to develop a model for the effective management of cultural tourism at the temples to maximise the visitor experience and minimise negative effects on the temples. Swot analysis produced the following results:

Strengths:

- The temples are places that combine art and philosophy and gather traditional knowledge to provide an endless learning heritage for local people.

- They are internationally famous cultural attractions and have been registered as world heritage sites. They help to maintain and conserve the artistic traditions of South East Asia.

- The temples are architectural, artistic and archaeological treasures that allow the continued inheritance of history.

- They contain remains of important royal figures.

- They were royally commissioned. 
- The government and private sectors help publicize cultural tourism at the temples.

- They are situated in convenient and easily-accessible locations.

- They provide income for the local community and support its economic strength.

Weaknesses:

- There is no government or private participation in tourism management and no systematic evaluation of service management.

- The temple space is limited so that the area is crowded during festivals.

- Public utilities are insufficient; especially litter bins and automatic teller machines. Toilets are dirty and there is not enough drinking water.

- There is no systematic budget management.

- Safety and security is inadequate.

- There is too little and unvaried publicity.

- There is no management of pets and strays in the temple area.

Opportunities:

- The temples are cultural tourist attractions in the Bangkok metropolitan area. They are easily reached with a good variety of communication links.

- They are centrally located in relation to other tourist attractions.

- The temples are open to tourists every day.

- The temple budgets are substantial and are not a limiting factor to tourism.

- Many academics and researchers are interested in the development of the temples and solving problems within.

Threats:

- People performing illegal occupations, such as thieves, touts and confidence tricksters frequent the temples at the weekend and during festivals. The temples are places of criminal activity.

- The products sold around the temples are not standardised and this influences the image of tourism at the temples.

- There is conflict over the distribution of benefits.

- The tourist mentality does not correspond to the regulations of the temples and they do not treat the ancient sites with due respect. The need for renovations and repairs each year is caused by ignorance.

- Some temple councils do not agree with development of the temples as tourist attractions.

- There is a lack of people inside the temples with an adequate knowledge of tourism management.

The semantic model created from the focus group discussion and workshop identifies eight groups to be involved in development: Temple managers and councillors, the government and private sector, cultural academics, the community, educational institutions, the general population, mass media and tourists. These groups should participate in five stages of temple development. The first stage is planning, whereby collective opinions must be given on the beauty of the site, maintenance of safety, public utilities, attraction of the religious place, guide services, advertising and public relations, varied tourist activities and efficient management. The second stage is analysis of current status. The groups must analyse the level of knowledge within the temple and its improvement through various activities for the benefit of cultural tourists. The activities that are run must be examined according to the standards of other tourist attractions throughout Thailand. The third stage is definition of an approach. The style of activities to be used to disperse knowledge and promote tourism must be outlined. Networks and connections for participation of all groups must be created. The activities should be designed to meet tourist needs and adapted for both domestic and international tourists. Plans must be made to accommodate both short and long-term tourists. The fourth stage is implementation. Each of the eight identified groups must participate in implementation of the plans, especially the Tourism Authority of Thailand. It is also important to integrate knowledgeable members of the local community. The temples and the local community must be readied to welcome tourists and the management teams must undergo continuous training. The temple staff must study the management of other domestic and international tourist sites and create new, culturally-appropriate methods 
of drawing tourists to their attractions. Problems must be continuously examined and corrective measures taken. An external committee must be invited to assess the temple management. The regulations of the temple should be clearly displayed and strictly enforced so that tourism does not detract from the purpose of the temple. The fifth stage is evaluation. By completion of follow-up evaluation, the Rattanakosin temples will be standardised and systematically regulated, the attractions will be strengthened and all parties will have a greater level of involvement. The development model for management of cultural tourism in temples of the Rattanakosin period was finalised at workshops in each of the nine temples studied and the results are summarised in eight major areas.

\subsubsection{The Temple Site}

The respondents felt that the aesthetic appearance of the temple must be improved. The respondents defined a four section approach to the project: clean the temple grounds, create a set of appropriate regulations for staff members, plant trees to create shade and repair sections of the grounds. For the first section, cleaning, public announcements will be made to call for community and government participation in cleaning the temple. Shifts will then be drawn up for the volunteers and monks and the number of litter bins will be increased. A program will be run with participation from the community and local schools under the title 'clean temple, clean hearts.' Members of the program will participate in an exercise to simultaneously clean the temple grounds and listen to Buddhist preaching. For the second section, regulating staff members, a set of rules will be outlined for appropriate sales behaviour in the temple, the shop models will be rearranged to correspond to the surrounding temple environment and a training course will be organised to ensure salesmen and women share the same standards. For the third section, development of temple environment, the gardens will be restored, new trees will be planted in pots or directly in the temple grounds and the number of gardeners will be increased. For the fourth section, renovations, a plan will be outlined to integrate ancient ruins, a plan will be devised to designate specific areas for attractions within the temple grounds, repairs will be carried out on broken parts of the temple and an official will be made responsible for tourist resources in the temple. Evaluation of the actions is expected to find the temple cleaner, the staff in line with temple regulations, the trees cared for by the gardeners and ruins beautifully integrated into the temple.

\subsubsection{Safety}

The plan of the respondents was to find a way to protect the tourists and their personal belongings, which are currently threatened by illegal operations in and around the temple. The plan is to be implemented in nine stages:

- Officials will be made responsible for tourist safety and security in areas of high risk.

- Warning leaflets will be handed out to tourists.

- Security cameras will be installed within the temple and in risk spots around the temple.

- A local police representative will be asked to participate in the security initiative.

- A warning notice will be posted at the local police station.

- Sufficient numbers of security guards will be hired in each temple.

- A report booth will be set-up for complaints.

- Related Buddhist teachings will be made into signs to deter lawbreakers from their actions.

- Volunteers will be requested from the local community to come and help monitor temple security.

Evaluation of the security initiative is expected to find security officials able to do their jobs more effectively and improved tourist safety.

\subsubsection{Conveniences}

With the planned aim of making tourist visits more convenient, four strategies were outlined. Firstly, the car parking areas will be developed by assigning parking officials, increasing the designated parking space and defining a fair and standard pricing system. Secondly, public conveniences will be improved by creation of a toilet maintenance rota, installation of lighting and provision of international standard refreshment facilities. Thirdly, tourist services will be enhanced by integration of local community members as trained guides, with instruction given to all staff members in service responsibilities and language proficiency. Finally, a sticker-book activity will be initiated. Tourists will be given leaflets and, if they gather stamps or stickers by visiting each of the nine temples, they will receive a gift. Evaluation is expected to find sufficient parking spaces, public utilities that meet tourist needs and tourists impressed by the level of service offered from temple staff.

\subsubsection{Attractions}


The research respondents felt the need to create attractions that impress visitors with use of temple resources. With this in mind, two approaches were devised: resource management and knowledge development. Concepts of knowledge marketing will be used to disperse information about the Rattanakosin temples, buildings will be renovated, monks and local community members will become involved in management and camps will be arranged for the monks to create harmony among members of the temple. The existing body of knowledge will be expanded by creation of documents and audio documentaries, which will be placed at different points within the temples. Local community members and students will be invited to become guides. The centres of learning within the temple complex will be cleaned, arranged and made more attractive to visitors. A variety of publicity will be used to reach all tourist groups. These methods are to include tourist maps and websites. A temple library or museum will be created to collect historical information and will be fitted with multimedia presentations to attract tourist interest. A foreign tourist survey must be conducted to determine the needs of international visitors and assess the languages that the temple must add to their documentation. A learning environment will be developed for all temple visitors. Evaluation is expected to find tourists more interested in the management of the temple and the knowledge centres able to attract visitors independently. It is also hoped that visitor satisfaction will increase.

\subsubsection{Service Capacity}

Six areas of improved service were outlined by the workshop participants as ways to improve the impression made by staff members. The existing temple staff will be trained in manners and culture of foreign countries. Tourist experiences will be evaluated and prizes will be awarded to staff given a high quality service rating. Refreshment kiosks will be cleaned. Regular rest points will be provided around the temple grounds. A uniform will be introduced for temple staff so that visitors may distinguish between official and unofficial workers. An evaluation point will be established for tourists to reveal their opinions on the service provide by temple staff. Evaluation is expected to find an increased rate of tourism and more systematic and reliable evaluation of temple staff.

\subsubsection{Public Relations}

With the aim of improving media-use in all areas of temple management, the respondents planned to increase the variety of media and publicity and direct its use towards the target groups of tourists. Current advertisements must be modernized and made clearer to understand in a variety of languages. With this in mind, publicity will be expanded to television, folding maps, the Internet, local hotels, Suvarnabhumi Airport and domestic and international tourist attractions. Tourist statistics will be recorded and monitored to judge the success of advertising and marketing. In addition, activities will be organised to support marketing and managed by a designated official. A marketing network will be established to include the government and private businesses and a website will be established and updated regularly. Evaluation is expected to show an increase in domestic and international visitors.

\subsubsection{Cultural Tourism}

The intention of research respondents is to increase the effectiveness, variety and benefit of cultural tourism for all parties. This will be achieved by creating culturally themed activities during big annual festivals, such as Songkran and Loi Krathong. Similar activities will also be run for tourists on important religious days, such as Asalha Puja. The activities arranged must showcase the inherited culture of the temple, such as the act of pouring water over Buddhist artefacts and the heads of the elderly during Songkran Festival. Tourists must be allowed and encouraged to participate. Evaluation is expected to reveal that tourists are impressed by the cultural activities and that tourists benefit from observation and participation.

\subsubsection{Management}

To improve the cultural tourism management of the temples, the respondents designed eight approaches: 1) restructuring of the management council to include all eight members of the pre-defined network of interested parties; 2) observation of cultural tourism development in other locations; 3) systematic planning and implementation of solutions to problems within the temple; 4) clear definition of temple regulations; 5) fair distribution of benefits; 6) emphasis on community participation; 7) stricter management of finances with a temple account under trust of the management committee; 8) verification and audit of expenses and benefits. Evaluation of these changes is expected to show a higher level of ability among management staff, a systemised and verifiable management procedure and a strong network of participants.

This model is summarized in Figure 1. 


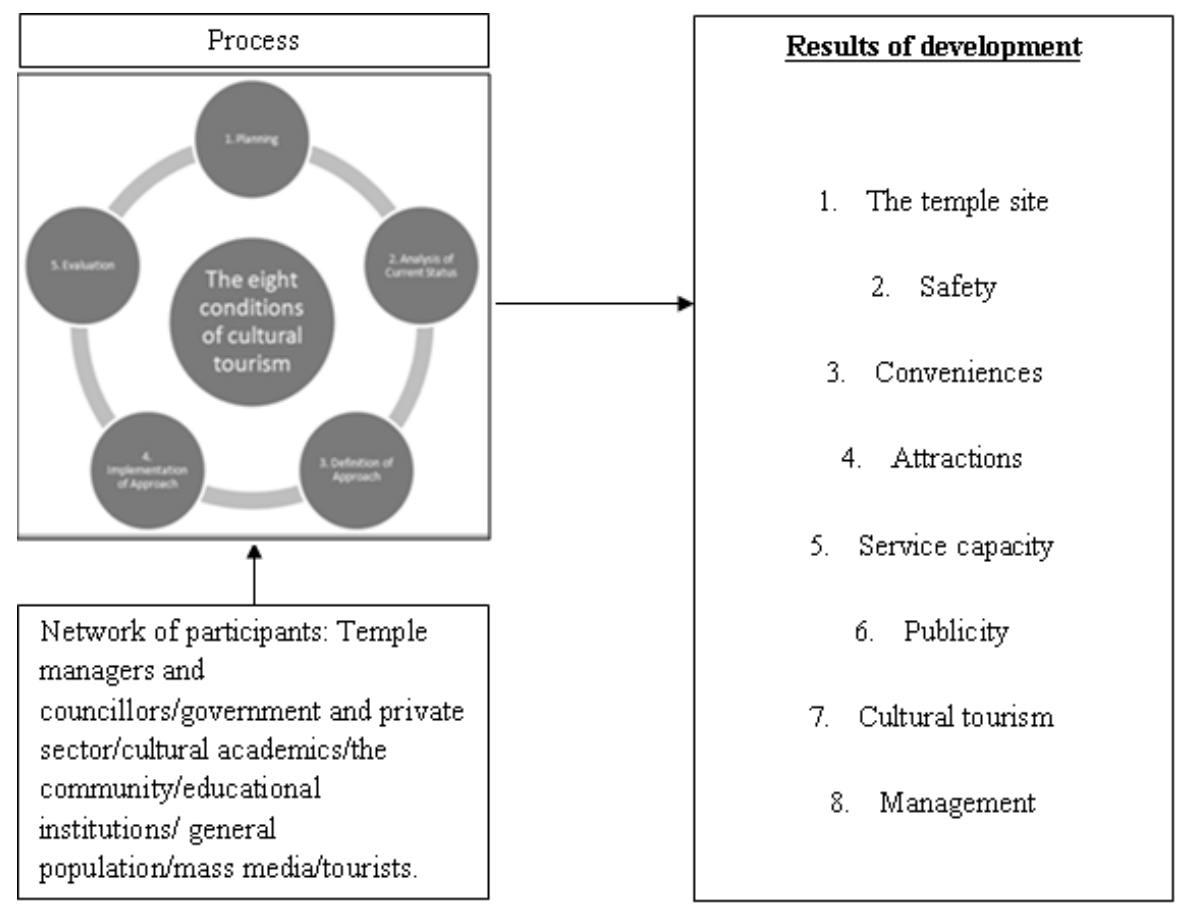

Figure 1. The development model for cultural tourism in Rattanakosin temples of Bangkok

\section{Conclusion}

The model designed during this investigation is an approach that was developed and accepted by members of nine Rattanakosin temples in Bangkok. The model aims to correct current problems with cultural tourism in Thai monasteries and provides an eight-part strategy for improved management. The outcome of this investigation can be applied to other temples in Thailand and abroad.

\section{References}

Angkoon, R., et al. (2001). Study of the readiness of temples in Bangkok regarding the dissemination of Buddhism through the observation of art culture [in Thai]. Nonthaburi: Sukhothaitammatirat University.

Buarapa, T. (2006). The development of a sustainable ecological and cultural tourism market in Khon Kaen Province [in Thai]. Maha Sarakham: Research Institute of Northeastern Art and Culture.

Chaisorn, J. (1993). Study of the conditions of tourist attractions in order to develop tourism in Mae Hong Son Province [in Thai]. Unpublished doctoral thesis, Srinakharinwirot University, Thailand.

Chantachon, S. (2006). A Comparative study of the development model in education and religion management process between Thailand and Lao PDR [in Thai]. Kalasin: Prasan Printing.

Cohen, J., \& Uphoff, N. (1977). Rural development participation: Concept and measures for project design implementation and evaluation. New York, NY: Prentice-Hall.

Coltman, M. (1989). Introduction to travel and tourism: An international approach. New York, NY: Abrams.

Department of Religious Affairs. (1994). Seminar documents for the project of providing knowledge in improving and conserving temples for monks at the instruction hall of Tam Kaw Temple, Mueang District, Mae Hong Son Province [in Thai]. Bangkok: Tourism Authority of Thailand.

Eber, S. (1992). Beyond the green horizon: A discussion paper on principles for sustainable tourism. Godalming: Worldwide Fund for Nature

Hiranyahat, R. (2001). Method of development to increase the potential of cultural villages for tourism: A case study of Ban Nong Kao, Ta Muang District, Kanjanaburi Province [in Thai]. Unpublished doctoral thesis, Srinakharinwirot University, Thailand.

Holloway, J. (1998). The business of tourism. Plymouth: Macdonald and Evens.

Hongsurapha, L. (2009). An appropriate model of conservation revival and development for the cultural forest 
temples in Northeastern Thailand by community participation. The Social Sciences, 4(5), 428-433.

Irwin, R. D. (1976). A handbook of management. London: Penguin.

Jantawanit, S. (2004). Qualitative research method [in Thai]. Bangkok: Chulalongkorn University Press.

Jantorn, B. (2002). Method for developing Don Wai Market, Sampran District, Nakhon Prathom Province as a cultural tourist attraction through community participation [in Thai]. Unpublished doctoral thesis, Chiang Mai University, Thailand.

Kaewmuang, D., \& Limpaluwan, L. (1998). Guide training handbook [in Thai]. Bangkok: Jankasem Rajabhat University.

Koontz, H., O’Donnel, C., \& Weihrich, H. (1986). Essentials of management. New York, NY: McGraw-Hill Book Company.

Kosit, A., et al. (2007). Research report of the problems and legal measures of tourism management in Chiang Rai Province [in Thai]. Bangkok: Thailand Research Fund

Laomee, B. (2009). Conservation and restoration of pulpits through the participation of Phu Thai people in Isan [in Thai]. Unpublished doctoral thesis, Mahasarakham University, Thailand.

Linitta, P. (2012). Wat Prachetponwimon Mangklaram: Potential development of cultural tourism to compete internationally [in Thai]. Unpublished doctoral thesis, Mahasarakham University, Thailand.

McGregor, D. (1960). The human side of enterprise. New York, NY: McGraw-Hill.

Menakanit, A. (1999). A royal temple in the Thai urban landscape: Wat Pho, Bangkok Thailand. College Station, TX: Texas A \& M University.

Nantee, N. (2001). Development of cultural tourist attractions: A case study of the Wat Pra Bat Huai Tom Community, Lee District, Lampoon Province [in Thai.]. Chiang Mai: Chiang Mai University.

Pakpinpet, S. (2008). Method for development of cultural tourism among Pao Yao people (Iewmien): A case study of Ban Huai Chompoo, Mueang District, Chiang Rai Province [in Thai]. Bangkok: Rangsit University.

Peleggi, M. (1996). National heritage and global tourism in Thailand. Annals of Tourism Research, 23(2), 432-448. http://dx.doi.org/10.1016/0160-7383(95)00071-2

Phromsarametee, P. (2010). Potential development of cultural tourist attractions for foreign tourists in Bangkok and the surrounding area [in Thai]. Unpublished doctoral thesis, Mahasarakham University, Mahasarakham.

Piwnim, M., \& Jansupan, P. (2003). Complete research report on development projects and their affect on tourism: A case study of floating market communities [in Thai]. Bangkok: Thailand Research Fund.

Prakrupaiboon Sornkit. (2009). Dharma tourism: Method for developing the potential of temples in Nakhon Ratchasima Province for cultural tourism [in Thai]. Unpublished doctoral thesis, Mahasarakham University, Thailand.

Prakru-wijitsangkakarn. (2009). Public opinion of cultural tourism management at Wat Sraket Ratchaworawihan, Bangkok [in Thai]. Bangkok: Krirk University.

Prathepweti. (1995). The role of ecclesiastical universities in Buddhist education leadership [in Thai]. Bangkok: Liangchiang.

Sukhothai Thammathirat Open University. (2002). The role of temples and monks for society and the community [in Thai]. Sukhothai Thammathirat Journal, 15(3), 5-7,

Swarbrooke, J. (1999). Sustainable tourism management. London: CABI Publishing.

Tanpronan, S. (1997). Opinions of abbots on the promotion of the Buddhist temples in Amphoe Muang Chiang Mai, Changwat Chiang Mai, as tourist attractions [in Thai]. Unpublished doctoral thesis, Kasetsart University, Thailand.

Tourism Authority of Thailand. (1996). Policy and approach of conservational tourism development [in Thai]. Bangkok: Ammarin Printing and Publishing.

Wisalaporn, S. (1991). Conflict: Service for creativity [in Thai]. Bangkok: Dakieng. 


\section{Copyrights}

Copyright for this article is retained by the author(s), with first publication rights granted to the journal.

This is an open-access article distributed under the terms and conditions of the Creative Commons Attribution license (http://creativecommons.org/licenses/by/3.0/). 